\title{
Lipidemic Properties of Sorghum vulgare Leaf Sheath on Oxidative Markers and Heart Function Enzymes of Dyslipidemic Wistar-Albino Rats
}

Akuru Udiomine $\mathrm{B}^{1 *}$ and OkokoTebekeme ${ }^{2}$

${ }^{1}$ Department of Biochemistry, Rivers State University of Science and Technology, Port Harcourt, Nigeria

${ }^{2}$ Department of Biochemistry, NDU, Bayelsa State, Nigeria

\begin{abstract}
Dyslipidemia is an abnormal amount of lipids such as triglycerides, cholesterol and/or fat phospholipids in the blood. The aim of this study was to investigate the lipidemic properties of Sorghum vulgare leaf sheath on oxidative markers and heart function enzymes on high-fat-diet induced dyslipidemic wistar-albino rats. Thirty-six (36) wistar-albino rats weighing 110-130 g were used for the study. The animals were distributed randomly into six groups of six animals each. Group 1 (control), group II to group VI were fed with high fat diet; group II (untreated), groups III to V received 400 $\mathrm{mg} / \mathrm{kg}, 800 \mathrm{mg} / \mathrm{kg}$ and $1200 \mathrm{mg} / \mathrm{kg}$ aqueous extract of Sorghum vulgare leaf sheath respectively while group VI was treated with atorvastatin $(0.2 \mathrm{mg} / \mathrm{kg})$ which is a standard drug. The results of the study showed that aqueous extract of Sorghum vulgare leaf sheath (especially at $800 \mathrm{mg} / \mathrm{kg}$ ) significantly reduced $(p \leq 0.05)$ body-weight, triglyceride concentration, very low density lipoprotein concentration, creatinine concentration and Lactate dehydrogenase activity. Malondialdehyde concentration, cholesterol concentration, glutathione peroxidase activity, creatine kinase activity and superoxide dismutase activity do not differ significantly $(p \leq 0.05)$. The results suggest that Sorghum vulgare leaf sheath has myocardial protective properties.
\end{abstract}

Keywords: Sorghum vulgare; Wistar-Albino rats; Oxidative markers

\section{Introduction}

Dyslipidemia is the elevation or attenuation of plasma lipoproteins. Metabolic disorders that involve elevations in any lipoprotein species are called hyperlipidemia or hypolipoproteinaemia [1]. Hyperlipidemia is characterized by high plasma concentrations of total cholesterol, low density lipoproteins (LDL), very low density lipoproteins (VLDL), triglycerides and reduced high density lipoproteins (HDL) concentrations. Hyperlipidemia is one of the risk factors contributing to the prevalence of atherosclerosis, stroke, coronary heart disease [2] and acute pancreatitis (caused majorly by hypertriglyceridemia) [3]

Synthetic drugs used in the treatment of dyslipidemiahave side effects [2] such as myopathy and hepatic dysfunction [1]. Hence use of herbal plants which have low side effects, cheap and readily available is of great importance [2]

Oxidative stress is highly correlated with a wide variety of inflammatory and metabolic disease states. It is highly correlated with cumulative damage in the body by free radicals when inadequately neutralized by antioxidants. Free radicals may adversely affect cell survival because of membrane damage through the oxidative damage of lipid, protein and irreversible DNA modification. Furthermore oxidative damage is aggravated by the decrease in antioxidant enzymes activities such as superoxide dismutase, catalase (CAT), glutathione S-transferase (GST), and glutathione peroxidase (GPx) which acts as a free radical scavengers in conditions associated with oxidative stress [4]. Hypertriglyceridemia and hypercholesterolemia was reported to be responsible for oxidative modification of LDL, protein glycation, glucose-autioxidation with excess production of free radicals and lipid peroxidation products, which may represent major risk factors for ischemic heart diseases.

Sorghum vulgare also called guinea corn is a member of the Poacea family which can strive in hot area. Phytochemicals present in Sorghum vulgare leaf sheath include tannins, flavonoids and phytate [5]. Phytate has shown to exhibit anti-inflammatory and cholesterol lowering effects. It also has antioxidant properties and metal chelating properties [6].
Flavonoids have antioxidant properties that can help in the reduction of oxidative stress that is associated with hyperlipidaemia [7].

\section{Methodology}

\section{Collection and Preparation of aqueous extract of the plants}

The dry plant was gotten from mile 3 market Port Harcourt, Nigeria. The plant was ground into fine powder with a blender and stored in an air tight container. The ground powder was macerated in distilled water for $12 \mathrm{~h}(1 \mathrm{~kg} / 1 \mathrm{~L})$. The macerate was filtered using Whatman filter paper (No 1), and the filtrate was concentrated using a water bath $\left(60^{\circ} \mathrm{C}\right)$ to obtain concentrated crude extract. The extract was stored in a freezer until further use [8].

\section{Experimental animals}

Thirty-six (36) Wister-albino rats weighing between 110-130 g were used for the study. The experiment lasted for a period of fortytwo days. The animals were acclimatized for a period of 14 days before use. Following acclimatization, the animals were distributed randomly into six groups of six animals each. Group 1 was the control and fed with growers feed only. Group II to group VI were induced with hyperlipidemia using high fat diet $(10 \mathrm{~g}$ of egg yolk per $40 \mathrm{~g}$ of the feed) for a period of four weeks. At the third week of inducement of hyperlipidemia with high fat diet, treatment of the animals with the

*Corresponding author: Akuru Udiomine, Department of Biochemistry, Rivers State University of Science and Technology, Port Harcourt, Nigeria, Tel: 7065563343 E-mail: minebrantley@gmail.com

Received: October 14, 2017; Accepted: November 14, 2017; Published November 22, 2017

Citation: Akuru Udiomine B, Tebekeme O (2017) Lipidemic Properties of Sorghum vulgare Leaf Sheath on Oxidative Markers and Heart Function Enzymes of Dyslipidemic Wistar-Albino Rats. Biochem Anal Biochem 6: 343. doi: 10.4172/2161 1009.1000343

Copyright: (C) 2017 Akuru Udiomine B, et al. This is an open-access article distributed under the terms of the Creative Commons Attribution License, which permits unrestricted use, distribution, and reproduction in any medium, provided the original author and source are credited. 
plant's extract and standard drug commenced for a period of two weeks. Group II was untreated; group III to V received $400 \mathrm{mg} / \mathrm{kg}, 800 \mathrm{mg} / \mathrm{kg}$ and $1200 \mathrm{mg} / \mathrm{kg}$ of the plant's aqueous extract respectively while group VI was treated with atorvastatin $(0.2 \mathrm{mg} / \mathrm{kg})$. At the end of the study, the animals were sacrificed and their blood samples were collected for biochemical study.

\section{Biochemical studies}

Total Cholesterol (TC), Triglycerides, (TG), Low Density Lipoprotein Cholesterol (LDL), High Density Lipoprotein Cholesterol (HDL) were assayed using Randox Kits (Randox laboratories Ltd, Crumlin, England, UK).MDA level was assessed using thiobarbituric acid reactive substances as described by Ohkawa, et al. [9]. Superoxide dismutase was measured according to Misra and Fridovich method [10]. GPx activity estimation was based on the rate of $\mathrm{H}_{2} \mathrm{O}_{2}$ consumption as described $[11,12]$. Creatine kinase and lactate dehydrogenase was determined using Seralyzer method [13]. Creatinine was determined by colorimetric method and urea concentrations were determined by urease-Berthelot method.

\section{Statistical analysis}

Data was represented as Mean \pm SEM, and subjected to One-way Analysis of Variance (ANOVA) using Statistical software SPSS. A level of $\mathrm{p} \leq 0.05$ was considered as statistically significant.

\section{Results and Discussion}

Obesity is a pathological condition in which there is accumulation of excess body fat, which results by taking more calories in diet than are expanded by the body's consuming activities. Arthrosclerosis and cardiac complications are more common among obese individuals [4].

The results on Table 1 show the weights of the hyperlipidemic animals. There was significant reduction $(\mathrm{p} \leq 0.05)$ of animals treated with $800 \mathrm{mg} / \mathrm{kg}$ of aqueous extract of Sorghum vulgare leaf sheath when compared to the control and hyperlipidemic animals.

Blood lipids as a whole participate as a key intermediate in atherogenesis [14]. The results of the aqueous extract of Sorghum vulgare leaf sheath on lipid profile of high fat diet induced dyslipidemic rats is shown in Table 2. There was significant reduction $(\mathrm{p} \leq 0.05)$ of triglyceride and VLDL concentration of all the groups compared to the hyperlipidemic untreated group. Indicating that the extract can be used in treating cardiovascular diseases. However, there was no significant reduction $(\mathrm{p} \leq 0.05)$ in total cholesterol, HDL and LDL levels of all the treated groups.

High fat diet has been reported to induce oxidative stress by causing lipid peroxidation. Lipid peroxidation is initiated by free radical attack on membrane polyunsaturated fatty acids leading to their transformation and fragmentation to alkanes and aldehyde reactive compounds. SOD is a primary oxygen radical scavenger of tissues converting the super oxide anion radical to $\mathrm{H}_{2} \mathrm{O}$ and $\mathrm{H}_{2} \mathrm{O}_{2}$. GPx acts as scavenger of hydrogen peroxide and other hydroperoxides $\left(\mathrm{H}_{2} \mathrm{O}_{2}\right.$ into $\mathrm{H}_{2} \mathrm{O}$ and $\left.\mathrm{O}_{2}\right)$ [15]. However, imbalance between the formation of reactive oxygen species and their elimination occasioned by dyslipidemia has been implicated in oxidative-induced diseases [16].

The results of the present study showed no significant difference ( $\mathrm{p}$ $\leq 0.05$ ) in all the groups for MDA and GPx levels (Table 3). But there was significant decrease $(\mathrm{p} \leq 0.05)$ in hyperlipidemic rats compared to the control of SOD level (Table 3 ) and an increase in those animals treated with $800 \mathrm{mg} / \mathrm{kg}$ of the plant extract when compared to the hyperlipidemic rats, though not significantly different $(\mathrm{p} \leq 0.05)$.

Lactate dehydrogenase, creatine kinase and aspartate amino transferase can be used as biomarkers of heart function. Lactate dehydrogenase is an enzyme that in all cells in the body mainly; liver, heart, kidneys, muscle and erythrocytes. LDH levels may be increased whenever there is cell necrosis or when neoplastic proliferation of cells causing an increase in $\mathrm{LDH}$ production. Elevated $\mathrm{LDH}$ activity also indicates tissue damage [17].

Creatine kinase (CK), is an intracellular enzyme present in greatest amounts in skeletal muscle, myocardium, and brain; smaller amounts occur in other visceral tissues. Disruption of cell membranes due to hypoxia or other injury releases CK from the cellular cytosol into the systemic circulation. Elevated CK activity can also be due to skeletal muscle damage and excessive exercise, myositis, and nutritional myopathy [17]. Aspartate aminotransferase (AST) leaks when the liver, heart, skeletal muscle or erythrocytes are injured [18]. It non-specific for liver damage but can also be used as cardiac marker.

\begin{tabular}{|c|c|c|c|c|}
\hline Groups & Initial weight $\mathbf{( g )}$ & After acclimatization (g) & $\begin{array}{c}\text { Weight after two weeks of } \\
\text { inducing hyperlipidemia (g) }\end{array}$ & $\begin{array}{c}\text { Weights of animals after treatment with } \\
\text { aqueous extract of Sorghum vulgare } \mathbf{( g )}\end{array}$ \\
\hline Control & $130.00^{\mathrm{a}} \pm 0.00$ & $131.16^{\mathrm{a}} \pm 1.66$ & $139.16^{\mathrm{a}} \pm 0.83$ & $140.00^{\mathrm{a}} \pm 2.04$ \\
\hline HFD & $118.30^{\mathrm{b}} \pm 1.05$ & $126.60^{\mathrm{a}} \pm 2.10$ & $134.16^{\mathrm{b}} \pm 1.53$ & $140.00^{\mathrm{a}} \pm 2.04$ \\
\hline HFDATV & $123.30^{\mathrm{b}} \pm 1.66$ & $125.00^{\mathrm{a}} \pm 0.84$ & $132.50^{\mathrm{b}} \pm 1.11$ & $145.00^{\mathrm{a}} \pm 2.04$ \\
\hline HFD400 & $117.50^{\mathrm{b}} \pm 1.11$ & $128.33^{\mathrm{a}} \pm 1.66$ & $134.16^{\mathrm{b}} \pm 1.53$ & $135.00^{\mathrm{ac}} \pm 2.04$ \\
\hline HFD800 & $122.50^{\mathrm{b}} \pm 2.14$ & $123.30^{\mathrm{a}} \pm 2.10$ & $132.50^{\mathrm{b}} \pm 1.11$ & $132.50^{\mathrm{abc}} \pm 1.44$ \\
\hline HFD1200 & $122.50^{\mathrm{b}} \pm 1.11$ & $125.00^{\mathrm{a}} \pm 2.23$ & $135.83^{\mathrm{b}} \pm 0.83$ & $136.25^{\mathrm{a}} \pm 2.39$ \\
\hline
\end{tabular}

Values are expressed as Mean \pm SEM. Values in a column with the same alphabetical superscript do not differ significantly ( $\mathrm{s} \leq 0.05$ ). Values in a column with different alphabetical superscript differ significantly $(p \leq 0.05)$.

Table 1: Weights of the hyperlipidemic animals

\begin{tabular}{|c|c|c|c|c|c|}
\hline Groups & $\mathrm{TC}(\mathrm{mmol} / \mathrm{l})$ & TG (mmol/l) & HDL (mmol/l) & LDL (mmol/l) & VLDL (mmol/l) \\
\hline Control & $3.60^{a} \pm 0.14$ & $2.05^{\mathrm{a}} \pm 0.06$ & $0.56^{\mathrm{a}} \pm 0.07$ & $1.77^{\mathrm{a}} \pm 0.28$ & $0.41^{\mathrm{a}} \pm 0.01$ \\
\hline HFD & $3.95^{\mathrm{a}} \pm 0.17$ & $2.90^{\mathrm{b}} \pm 0.17$ & $0.79^{\mathrm{a}} \pm 0.06$ & $0.52^{b} \pm 0.30$ & $0.58^{b} \pm 0.03$ \\
\hline HFDATV & $4.22^{a} \pm 0.18$ & $2.30^{\mathrm{a}} \pm 0.25$ & $0.67^{a} \pm 0.01$ & $1.62^{\mathrm{a}} \pm 0.11$ & $0.46^{a} \pm 0.05$ \\
\hline HFD400 & $4.55 \pm 0.80$ & $2.15^{\mathrm{a}} \pm 0.06$ & $0.81^{a} \pm 0.07$ & $1.80^{\mathrm{a}} \pm 0.17$ & $0.43^{a} \pm 0.01$ \\
\hline HFD800 & $3.62^{a} \pm 0.35$ & $2.15^{\mathrm{a}} \pm 0.17$ & $0.99^{\mathrm{a}} \pm 0.09$ & $0.84^{b} \pm 0.44$ & $0.43^{a} \pm 0.03$ \\
\hline HFD1200 & $4.02^{a} \pm 0.11$ & $2.22^{\mathrm{a}} \pm 0.06$ & $0.98^{\mathrm{a}} \pm 0.06$ & $0.81^{b} \pm 0.12$ & $0.44^{\mathrm{a}} \pm 0.01$ \\
\hline
\end{tabular}

Values are expressed as Mean \pm SEM. Values in a column with the same alphabetical superscript do not differ significantly ( $\leq \leq 0.05)$. Values in a column with different alphabetical superscript differ significantly $(p \leq 0.05)$.

Table 2: Results of the aqueous extract of Sorghum vulgare leaf sheath on lipid profile of high fat diet induced dyslipidemic rats. 
Citation: Akuru Udiomine B, Tebekeme O (2017) Lipidemic Properties of Sorghum vulgare Leaf Sheath on Oxidative Markers and Heart Function Enzymes of Dyslipidemic Wistar-Albino Rats. Biochem Anal Biochem 6: 343. doi: 10.4172/2161-1009.1000343

Page 3 of 4

\begin{tabular}{|c|c|c|c|}
\hline Groups & MDA (U/L) & GPX (U/L) & SOD (U/L) \\
\hline Control & $1.82^{\mathrm{a}} \pm 0.23$ & $0.25^{\mathrm{a}} \pm 0.22$ & $0.69^{\mathrm{a}} \pm 0.07$ \\
\hline HFD & $1.42^{\mathrm{a}} \pm 0.29$ & $0.30^{\mathrm{a}} \pm 0.01$ & $0.12^{\mathrm{b}} \pm 0.01$ \\
\hline HFDATV & $2.45^{\mathrm{a}} \pm 0.27$ & $0.23^{\mathrm{a}} \pm 0.02$ & $0.25^{\mathrm{b}} \pm 0.05$ \\
\hline HFD400 & $1.92^{\mathrm{a}} \pm 0.12$ & $0.24^{\mathrm{a}} \pm 0.03$ & $0.17^{\mathrm{b}} \pm 0.03$ \\
\hline HFD800 & $1.42^{\mathrm{a}} \pm 0.27$ & $0.25^{\mathrm{a}} \pm 0.03$ & $0.23^{\mathrm{b}} \pm 0.06$ \\
\hline HFD1200 & $1.62^{\mathrm{a}} \pm 0.27$ & $0.34^{\mathrm{a}} \pm 0.03$ & $0.19^{\mathrm{b}} \pm 0.04$ \\
\hline
\end{tabular}

Values are expressed as Mean \pm SEM. Values in a column with the same alphabetical superscript do not differ significantly $(p \leq 0.05)$. Values in a column with different alphabetical superscript differ significantly $(p \leq 0.05)$.

Table 3: Results of the aqueous extract of Sorghum vulgare leaf sheath on oxidative markers on high fat diet induced dyslipidemic rats.

\begin{tabular}{|c|c|c|}
\hline Groups & LDH & CK \\
\hline Control & $14.22^{\mathrm{bc}} \pm 4.18$ & $4.40^{\mathrm{bc}} \pm 1.62$ \\
\hline HFD & $22.40^{\mathrm{b}} \pm 2.05$ & $6.07^{\mathrm{b}} \pm 0.36$ \\
\hline HFDATV & $31.65^{\mathrm{b}} \pm 1.54$ & $7.95^{\mathrm{be}} \pm 0.17$ \\
\hline HFD400 & $23.22^{\mathrm{b}} \pm 2.94$ & $6.65^{\mathrm{b}} \pm 0.50$ \\
\hline HFD800 & $9.77^{\mathrm{bc}} \pm 2.94$ & $5.50^{\mathrm{a}} \pm 0.38$ \\
\hline HFD1200 & $23.75^{\mathrm{b}} \pm 0.84$ & $6.87^{\mathrm{b}} \pm 0.28$ \\
\hline
\end{tabular}

Values are expressed as Mean \pm SEM. Values in a column with the same alphabetical superscript do not differ significantly $(p \leq 0.05)$.Values in a column with different alphabetical superscript differ significantly $(p \leq 0.05)$.

Table 4: Heart function enzymes of dyslipidemic animals treated with aqueous extract of Sorghum vulgare leaf sheath.

\begin{tabular}{|c|c|c|c|}
\hline Groups & UR $(\mathbf{m m o l} / \mathbf{L})$ & $\mathbf{C R}(\boldsymbol{\mu m o l} / \mathbf{L})$ & AST $(\mathbf{U} / \mathbf{L})$ \\
\hline Control & $5.67^{\mathrm{a}} \pm 0.19$ & $115.50^{\mathrm{a}} \pm 6.88$ & $172.25^{\mathrm{bc}} \pm 2.25$ \\
\hline HFD & $3.22^{\mathrm{b}} \pm 0.10$ & $130.00^{\mathrm{b}} \pm 1.87$ & $190.05^{\mathrm{b}} \pm 3.22$ \\
\hline HFDATV & $3.56^{\mathrm{b}} \pm 0.28$ & $152.00^{\mathrm{ab}} \pm 2.85$ & $203.50^{\mathrm{b}} \pm 2.25$ \\
\hline HFD400 & $2.72^{\mathrm{b}} \pm 0.10$ & $144.00^{\mathrm{b}} \pm 9.54$ & $177.50^{\mathrm{bc}} \pm 4.29$ \\
\hline HFD800 & $4.12^{\mathrm{b}} \pm 0.10$ & $117.75^{\mathrm{a}} \pm 5.37$ & $167.00^{\mathrm{bc}} \pm 2.04$ \\
\hline HFD1200 & $3.97^{\mathrm{b}} \pm 0.36$ & $140.00^{\mathrm{b}} \pm 4.14$ & $191.75^{\mathrm{b}} \pm 3.14$ \\
\hline
\end{tabular}

Values are expressed as Mean \pm SEM. Values in a column with the same alphabetical superscript do not differ significantly $(p \leq 0.05)$. Values in a column with different alphabetical superscript differ significantly $(p \leq 0.05)$.

Table 5: Results of the aqueous extract of Sorghum vulgare leaf sheath Kidney function indices on high fat diet induced dyslipidemic rats.

Table 4 shows the results of the heart function enzymes of dyslipidemic animals treated with aqueous extract of Sorghum vulgare leaf sheath. There was a significant reduction $(\mathrm{p} \leq 0.05)$ of LDH activity of hyperlipidemic animals treated with $800 \mathrm{mg} / \mathrm{kg}$ of aqueous extract of Sorghum vulgare leaf sheath and the control group when compared to the high fat diet untreated animals. In addition, there was reduction though not significant $(\mathrm{p} \leq 0.05)$ of CK activity of hyperlipidaemic animals treated with $800 \mathrm{mg} / \mathrm{kg}$ of aqueous extract of Sorghum vulgare leaf sheath and control group when compared to the hyperlipidemic untreated animals. Furthermore, there was significant reduction ( $\mathrm{p}$ $\leq 0.05)$ in AST activity of hyperlipidemic animals treated with 400 $\mathrm{mg} / \mathrm{kg}$ and $800 \mathrm{mg} / \mathrm{kg}$ of aqueous extract of Sorghum vulgare sheath when compared to the hyperlipidemic untreated animals and the hyperlipidemic animals treated with $0.2 \mathrm{mg} / \mathrm{kg}$ of atorvastatin. The result suggests that aqueous extract of Sorghum vulgare leaf sheath may have myocardial protective effect.

Chronic kidney disease (CKD) is defined by reduction in Glomerular Filtration Rate (GFR). As GFR declines, urinary excretion of urea and creatinine also reduces and blood concentration of creatinine and urea increases [19]. From the results presented on Table 5 , there was significant reduction $(\mathrm{p} \leq 0.05)$ of creatinine concentration for animals treated with $800 \mathrm{mg} / \mathrm{kg}$ aqueous extract of Sorghum vulgare leaf sheath when compared to the hyperlipdemic untreated animals.

The urea concentration of the treated animals was within range (2.8-8.9 $\mathrm{mmol} / \mathrm{L}$ ) for all the groups [20-22].

\section{Conclusion}

The results suggest that aqueous extract of Sorghum vulgare leaf sheath (at $800 \mathrm{mg} / \mathrm{kg}$ ) has anti-hypertriglyceridemic properties, nephroprotective and myocardia-protective effect.

\section{References}

1. Mally JM, Kane PJ (2010) Agents used in dyslipidaemia. Basic and clinical pharmacology Pp: 619-633.

2. Subbramaniam S, Subbramaniam R, Uthrapathi S, Victor GR, Dubey PG (2011) Antihyperlipidemic and antioxidant potential of different fractions of Terminialiaarjuma Rox b. bark against PX-407 induced hyperlipidemia. Indian journal of experimental biology 49: 282-288.

3. Brunzell JD (2007) Hypertriglyceridemia. The New England Journal of Medicine 357: 1009-1017.

4. Noeman SA, Hala EH, AmalA B (2011) Biochemical Study of Oxidative Stress Markers in the Liver, Kidney and Heart of High Fat Diet Induced Obesity in Rats. Diabetology \& Metabolic Syndrome 3: 17.

5. Oyetayo FL, Ifedayo OA (2012) Guinea Corn (Sorghum vulgare) Leaf, Potential Source of Nutrients and Phytochemicals. Food and Public Health 2: 228-230.

6. Nwiloh BI, Uwakwe AA, Akaninwor JO (2016) Phytochemical screening and GC-FID analysis of ethanolic root back of Salacia nitida. L. Benth. Journal of Medical plants Studies 4: 283-287.

7. Beyegue CFN, Ngangoum RMC, Kuate D, Ngondi JL, Oben JE (2012) Effect of Guibourtiatessmanniiextracts on blood lipids and oxidative stress markers in triton WR 1339 and high fat diet induced hyperlipidemic rats. Biology and Medicine 4: 1-9.

8. Fidele N, Kakesse M, Hamadjida A, Paul FSE, Theophile D (2015) Hypolipidemic antioxidant and anti atherosclerogenic effects of aqueous extract of Zanthorylumheitziisrem bark in diet-induced hypercholesterolemic rats. Asian pacific Journal of Tropical Medicine 8: 359-365.

9. Ohkawa H, Ohishi N, Yagi K (1979) Assay for lipid peroxides in animal tissues by thiobarbituric acid reaction. Anal. Biochem 95: 351-358.

10. Misra HP, Fridovich I (1972) The role of superoxide anion in the autoxidation of epinephrine and a simple assay for superoxide dismutase. J Biol Chem 247: 3170-3175.

11. Rotruck JT, Pope AL, Ganther HE, Swanson AB, Hofeman DG, et al., (1973) Selenium: biochemical role as a component of glutathione peroxidase. Science 179: $588-590$.

12. Komolafe K, Akinmoladun AC, Olaleye MT, Akindahunsi A (2013) Methanolic leaf extract of Parkiabiglobosaprotects against doxorubicin-induced cardiotoxicity in rats. International Journal of Applied Research in Natural Products 6: 39-47.

13. Stevens JF, Tsang W, Newall RG (1983) Measurement of the enzyme lactate dehydrogenase and cratine kinase using reflectance spectroscopy and reagent strip. J Clin Path 36: 1371-1376.

14. Eqbal MA, Aminah A, Halimah AS (2012) Lipid Profile and Antioxidant Enzymes in Normal and Stressed Rat Fed with Palm Olein. American Journal of Applied Sciences 9: 1071-1078.

15. Li Z, Labek VZ, Velisek J, Machoval J, Kolaroval J, et al., (2011) Antioxidant responses and plasma biochemical characteristics in the freshwater rainbow trout, Oncorrhynchusmykisss, after exposure to fungicide propiconazole. Czecg j amim Sci 56: 61-69.

16. Sinbad O, Bradley G, Anthony AJF (2012) Protective Effect of T. Violacea Rhizome Extract Against Hypercholesterolemia-Induced Oxidative Stress in wistar Rats. Molecules 17: 6033-6045.

17. Arika WM, Nyamai DW, Osano KO, Ngugi MP, Njagi ENM (2016) Biochemica Markers of In Vivo Hepatotoxicity. Journal of Clinical Toxicology 6: 297: 1-8.

18. Philip H, Johnny C (2012) What is the Real Function of the Liver 'Function' Tests. Ulster Medical Journal 81: 30-36. 
Citation: Akuru Udiomine B, Tebekeme O (2017) Lipidemic Properties of Sorghum vulgare Leaf Sheath on Oxidative Markers and Heart Function Enzymes of Dyslipidemic Wistar-Albino Rats. Biochem Anal Biochem 6: 343. doi: 10.4172/2161-1009.1000343

Page 4 of 4

19. Haggins C (2016) Urea and creatinine concentration, the urea: creatinine ratio. Acute care testing

20. Hossein F, Ozra T (2012) Dyslipidemia and cardiovascular disease-from prevention to treatment. Pp: 303-321.
21. Muan G. Khalid ZA, Hegele RA (2007) Hypertriglyceridemia:itsetiology, effects and treatment(Review). Canadian Medical Association Journal 176: 1113-1120.

22. Schulpis K, Karikas GA (1998) Serum cholesterol and triglyseride distribution in 7767 school-aged greek children. Pediatrics 101: 861-864. 